\title{
Responses of Soybean (Glycine max L.) Varieties to NPS Fertilizer Rates at Bako, Western Ethiopia
}

\author{
Dame Oljirra, Tasisa Temesgen* \\ School of Natural Resource Management and Environmental Sciences, Haramaya University, Dire Dawa, Ethiopia
}

\section{Email address:}

tasisatemesgen@gmail.com (T. Temesgen)

${ }^{*}$ Corresponding author

\section{To cite this article:}

Dame Oljirra, Tasisa Temesgen. Responses of Soybean (Glycine max L.) Varieties to NPS Fertilizer Rates at Bako, Western Ethiopia. American Journal of Water Science and Engineering. Special Issue: Soil, irrigation and Water Management.

Vol. 5, No. 4, 2019, pp. 155-161. doi: 10.11648/j.ajwse.20190504.13

Received: September 27, 2019; Accepted: November 6, 2019; Published: November 27, 2019

\begin{abstract}
Soybean (Glycine max. L) is among the most important legume crops produced in western Ethiopia. However, declining soil fertility and poor soil fertility management practices decrease yields. A field experiment was conducted in Bako Agricultural Research center during 2018 main cropping season to investigate the effect of NPS rates on yield and yield components of soybean varieties and to identify economically feasible rates of blended NPS rate that increase the productivity. Dhidhessa, Ethio-yugoslavia and Wello of soybean varieties and five rates of NPS $\left(0,50,100,150\right.$ and $\left.200 \mathrm{~kg} \mathrm{ha}^{-1}\right)$. The experiment was laid out in arrangement in RCBD with three replications. The highest hundred seed weight $(16.9 \mathrm{~g})$ was recorded from Ethio-yugoslavia and the lowest $(15 \mathrm{~g})$ from Wello. Significant effect was exhibited on days to $50 \%$ flower, above ground biomass yield and seed yield due to main effects of NPS rate. The highest (55.78) and the lowest (53.78) numbers of days to flowering were recorded due to application of $200 \mathrm{~kg} \mathrm{NPS} \mathrm{ha}^{-1}$ and $0 \mathrm{~kg} \mathrm{NPS} \mathrm{ha}^{-1}$, respectively. The tallest $(81.63 \mathrm{~cm})$ and the shortest $(65.60 \mathrm{~cm})$ plants were recorded under $200 \mathrm{~kg} \mathrm{NPS} \mathrm{ha}^{-1}$ and $0 \mathrm{~kg}$ NPS ha ${ }^{-1}$, respectively. The highest $\left(8718 \mathrm{~kg} \mathrm{ha}^{-1}\right)$ above ground dry mass was obtained at the highest rate of $200 \mathrm{~kg} \mathrm{NPS} \mathrm{ha}^{-1}$ and the lowest $\left(6910 \mathrm{~kg} \mathrm{ha}^{-1}\right)$ was due to $0 \mathrm{~kg} \mathrm{NPS} \mathrm{ha}^{-1}$. The highest $\left(2763 \mathrm{kgha}^{-1}\right)$ seed yield was recorded from the application of $100 \mathrm{kgha}^{-1} \mathrm{NPS}_{\text {rate }}$ and the lowest $\left(1935 \mathrm{kgha}^{-1}\right)$ seed yield was recorded from nil application of NPS fertilizer rate. The best combination with high grain yield and economic benefit is $100 \mathrm{kgha}^{-1}$ NPS fertilizer rate with Didhessa Variety. The major measured parameters contributing for grain yield were above ground biomass, number of pod per plant and no of primary branch per plant. This experiment generally confirmed as $100 \mathrm{kgha}^{-1}$ NPS for soybean was appropriate. This trial was conducted at strong acid soil, these it is expected as the plants might not have access to use the applied fertilizer and if it was conducted with lime application the responses might be changed. Thus, it can be concluded that combined application of $100 \mathrm{~kg} \mathrm{ha}^{-1}$ of blended NPS with Dhidhessa variety could be used at similar agro ecology. However, since the study was conducted for one season at one location, it has to be repeated over seasons and locations to make a conclusive recommendation.
\end{abstract}

Keywords: Blended Fertilizer, Nitrogen, Phosphorus, Sulfur, Yield Component

\section{Introduction}

Soybean was first introduced to Ethiopia in 1950's because of its nutritional value, multipurpose use and wider adaptability in different cropping systems [1]. It is a crop that can play major role as protein source for resource poor farmers of Ethiopia who cannot afford animal products. Besides, it can also be used as oil crop, animal feed, poultry meal, for soil fertility improvement and more importantly as source of foreign exchange earnings for the country [2]. In
Ethiopia, soybean has adapted to diverse ecological niches and provided wider yield range [1].

Soybean was produced on about $38,166.04$ ha of land and 81241.833 tons produced in $2015 / 16$ main cropping season with the productivity of $2.1 \mathrm{t} \mathrm{ha}^{-1}$; which is low as compared to world average of $2.6 \mathrm{t} \mathrm{ha}^{-1}$ [3]. This low yield may be attributed to a combination of several production constraints among which low soil fertility, periodic moisture stress, 
diseases and insect-pests, weeds and poor crop management practices play a major role [4]. Soybean is known for its wide adaptability coupled with its higher productivity per unit area compared to other grain legumes [5]. However, it is mostly cultivated in tropical and subtropical areas, where the soils are often deficient in phosphorus $(\mathrm{P})$ and nitrogen $(\mathrm{N})$ due to intensive erosion, weathering, and $\mathrm{P}$ fixation by free $\mathrm{Fe}$ and Al oxides [6]. Therefore, low $\mathrm{P}$ availability is often a major constraint to soybean growth and production [7]. Use of Pefficient soybean varieties with efficient $\mathrm{P}$ acquisition ability from both native and added $P$ sources in the soils would be a sustainable and economical approach [6].

Legumes require $\mathrm{P}$ for adequate growth and $\mathrm{N}$ fixation and their effectiveness in soil improvement can be hindered by $\mathrm{P}$ deficiency [8]. Phosphorus deficiency can limit nodulation by legumes and $\mathrm{P}$ fertilizer application can overcome the deficiency [9]. $\mathrm{N}_{2}$ fixation apparatus could not meet $\mathrm{N}$ demand [10]. However, yield response of soybean to fertilizer $\mathrm{N}$ has been inconsistent at economically acceptable levels $[11,12]$.

A Bako midland of West Showa Zone of western Ethiopia is one of the midland parts of the country that grows soybean. But it is affected by the low soil fertility problem. To address these nutrient deficiencies, farmers in the study area have been using uniform blanket application of $100 \mathrm{~kg} \mathrm{DAP} \mathrm{ha}^{-1}$ (18 kg N and $46 \mathrm{~kg} \mathrm{P}_{2} \mathrm{O}_{5} \mathrm{ha}^{-1}$ ) for all legumes including Soybean to increase crop yields and this did not consider soil fertility status and crop requirement.

However, the soil fertility mapping project in Ethiopia reported the deficiency of $\mathrm{K}, \mathrm{S}, \mathrm{Zn}, \mathrm{B}$ and $\mathrm{Cu}$ in addition to $\mathrm{N}$ and $\mathrm{P}$ in major Ethiopian soils and thus recommend application of customized and balanced fertilizers [13]. This emphasizes the importance of developing an alternative means to meet the demand of nutrient in plants by using of blending NPS that contains $\mathrm{S}$ in addition to the commonly used $\mathrm{N}$ and $\mathrm{P}$ fertilizers. However, there is limited information on responses of soybean varieties to rates of blended NPS fertilizer rates at Bako, Western Ethiopia.

Objective of the study:

1) To assess the effects of blended NPS fertilizer rates on the yield and yield components of soybean varieties.

2) To estimate cost-benefit of blended NPS rate that increases the productivity of the soybean varieties.

\section{Materials and Methods}

\subsection{Description of the Study Area}

The experiment was carried out during the main cropping season (June to November) of 2018 at Bako Agricultural Research Center (BARC) which is located in western Ethiopia and located at an altitude of $1650 \mathrm{~m}$ above sea level $09^{\circ} 6$ '00" N latitude and $37^{\circ} 09^{\prime} 00^{\prime \prime}$ E longitude.

\subsection{Soil Sampling and Analysis}

Pre-planting soil samples were taken randomly in a zigzag method from the experimental plots at the depth of $0-30 \mathrm{~cm}$ before planting. A representative soil samples were taken using a cylindrical auger from the whole experimental field and combined to form a composite sample. The collected soil sample was air-dried at room temperature under shade and ground to pass through $2 \mathrm{~mm}$ sieve for laboratory analysis. The composite soil samples were analyzed for selected physicochemical properties mainly textural analysis, soil $\mathrm{pH}$, total nitrogen $(\mathrm{N})$, available Sulfur (S), organic carbon (OC), available phosphorus (P), cation exchange capacity (CEC) (c mol kg-1), exchangeable potassium, magnesium and calcium using the appropriate laboratory procedures at Bako Agricultural Research Center Soil Laboratory.

Soil texture was determined by Boycous Hydrometer Method. Organic carbon (OC) was estimated by wet digestion method and organic matter was calculated by multiplying the $\mathrm{OC} \%$ by a factor of 1.724 . Total $\mathrm{N}$ was analyzed by Kjeldhal method [14]. The soil $\mathrm{pH}$ was measured potentiometrically in 1:2.5 soil-water suspensions with standard glass electrode $\mathrm{pH}$ meter [15]. Cation Exchangeable Capacity (CEC) was determined by leaching the soil with neutral $1 \mathrm{~N}$ ammonium acetate [16]. Available phosphorus was determined by the Olsen's method using a spectrophotometer [17]. Available sulfur (S) was measured using turbidimetric method [13].

\subsection{Treatments and Experimental Design}

The treatments were factorial combinations of five blended NPS fertilizer rates $\left(0,50,100,150,200 \mathrm{~kg} \mathrm{ha}^{-1}\right)$ and three varieties of soybean (Dhidhessa, Ethio-Yugoslavia and Wello). Those Varieties are grown by majority of the farmers of the study area and highly adaptable to areas of mid and low altitudes.

Table 1. Description of the varieties used for the study.

\begin{tabular}{llll}
\hline \multirow{2}{*}{ Adaptation/Attributes } & Variety & Wello \\
\cline { 2 - 4 } & Ethio-Yugoslavia & Dhidhessa & $750-1850$ \\
\hline Altitude (m. a.s. 1) & $1900-1200$ & $1200-1900$ & $660-1025$ \\
Rainfall amount (mm) & $1000-1200$ & $1000-1200$ & 121 \\
Days to maturity & $145-154$ & $137-145$ & Bush and half trailing type \\
Growth habit & Indeterminate & Indeterminate & Medium \\
Maturity group & Late & Medium & \\
Yield (t ha ${ }^{-1}$ ) & & & $1.92-3.2$ \\
Research field & $1.7-3.5$ & $2-3.3$ & $1.7-2.2$ \\
Farmers field & $1.6-3.0$ & $1.4-2.8$ & 2012 \\
Year of release & 2008 & 2008 & SARC \\
Releasing Institution & BARC & BARC & \\
\hline
\end{tabular}

Source: MoARD, 2008; MoARD, 2012. 
The NPS rate is based on blanket recommendation rate of $100 \mathrm{~kg} \mathrm{ha}{ }^{-1}$. The experiment was laid out as randomized complete block design (RCBD) and replicated three times. The gross plot size was $3.0 \mathrm{~m} \times 2.8 \mathrm{~m}=8.4 \mathrm{~m}^{2}$. The spacing between blocks and plots were $1.0 \mathrm{~m}$ and $0.6 \mathrm{~m}$, respectively. Each plot has 7 rows spaced $40 \mathrm{~cm}$ apart. The spacing between plants within row was $10 \mathrm{~cm}$. One outer most row on each side of the plot and two plants $(20 \mathrm{~cm})$ on each end of rows were considered as border. One row next to the border rows on any side was used for destructive sampling. The middle 4 rows were used as net rows. The net plot size was $2.6 \mathrm{~m} \times 1.6 \mathrm{~m}=4.16 \mathrm{~m}^{2}$.

Table 2. Treatment Combinations of Soybean Varieties and fertilizer rates.

\begin{tabular}{lllll}
\hline \multirow{2}{*}{ Treatment and code } & $\begin{array}{l}\text { NPS rates } \\
\text { (kg ha }\end{array}$ & \multicolumn{3}{c}{ Nutrient rates $\left(\mathbf{k g ~ h a}^{-\mathbf{1}}\right)$} \\
\cline { 2 - 5 } & $\mathbf{N}$ & $\mathbf{P}_{\mathbf{2}} \mathbf{O}_{\mathbf{5}}$ & $\mathbf{S}$ \\
\hline Ethio-Yugoslavia (T1) & 0 & 0 & 0 & 0 \\
Ethio-Yugoslavia (T2) & 50 & 9.5 & 19 & 3.5 \\
Ethio-Yugoslavia (T3) & 100 & 19 & 38 & 7 \\
Ethio-Yugoslavia (T4) & 150 & 28.5 & 57 & 10.5 \\
Ethio-Yugoslavia (T5) & 200 & 38 & 76 & 14 \\
Dhidhessa (T6) & 0 & 0 & 0 & 0 \\
Dhidhessa (T7) & 50 & 9.5 & 19 & 3.5 \\
Dhidhessa (T8) & 100 & 19 & 38 & 7 \\
Dhidhessa (T9) & 150 & 28.5 & 57 & 10.5 \\
Dhidhessa (T10) & 200 & 38 & 76 & 14 \\
Wello (T11) & 0 & 0 & 0 & 0 \\
Wello (T12) & 50 & 9.5 & 19 & 3.5 \\
Wello (T13) & 100 & 19 & 38 & 7 \\
Wello (T14) & 150 & 28.5 & 57 & 10.5 \\
Wello (T15) & 200 & 38 & 76 & 14 \\
\hline
\end{tabular}

\subsection{Experimental Procedure and Crop Management}

The land were ploughed by tractor, disked and harrowed. The plots were leveled manually. All the varieties were sown on mid June 2018. The different rates of blended NPS were applied by drilling in prepared rows before planting. The seeds were planted by hand at a specified spacing $(40 \mathrm{~cm} \times 10 \mathrm{~cm})$ by placing two seeds per hill and later thinned to one plant per hill after emergence. Furthermore, all necessary cultural and agronomic practices were carried out uniformly for all plots as per the recommendation for the crop at all stages of growth and development. The crop was harvested manually when $90 \%$ of the leaves and pods turned yellow and dried under the Sun before threshing. Threshing was done separately for each plot manually.

\subsection{Data Collected}

\subsubsection{Economic Analysis}

Economic analysis was performed using partial budget analysis following the procedure described [17] in which prevailing market prices for inputs at planting and for outputs at harvesting were used. All costs and benefits were calculated on ha basis in Birr. The net benefit (NB) was calculated as the difference between the gross benefit and the total cost.

\subsubsection{Statistical Data Analysis}

All the recorded data were subjected to analysis of variance using Gen Stat statistical software procedure. Least significant difference (LSD) test was used to compare treatment mean differences at the probability level of 0.05 .

\section{Results and Discussion}

\subsection{Physico-chemical Properties of the Experimental Site Soil}

The result of the experimental soil indicated that the soil textural class at Bako is clay with a particle size distribution of $69.36 \%$ clay, $13.98 \%$ silt and $14.8 \%$ sand (Table 3 ). The soil reaction is very strongly acid $\mathrm{pH} 4.84$ [18]. Organic carbon content of the soil is $1.3 \%$ which was rated as low as per the classification [19]. The available $P$ level in the experimental site was which is $9.6 \mathrm{mg} \mathrm{kg}^{-1}$ is low $[19,20]$. The result showed that the CEC of the experimental soil to be $23 \mathrm{meq} / 100 \mathrm{~g}$ soils rated as moderate according to rating the CEC values were lower than the mean of $48.2 \mathrm{cmolckg}^{-}$ ${ }^{1}$ presented in that material for soils of Ethiopia [18]. The analysis for available sulfur also indicated that the experimental soil had values of $11.74 \mathrm{mg} / \mathrm{kg}$.

Table 3. Physico-chemical properties of the experimental site soil before planting.

\begin{tabular}{llll}
\hline Characters & Value & Rating & Reference \\
\hline A. Soil texture & & & \\
Sand (\%) & 14.8 & & \\
Silt (\%) & 13.98 & & \\
Clay (\%) & 69.36 & & {$[21]$} \\
Textural Class & Clay & & \\
B. Chemical analysis & & & \\
Soil pH & 4.84 & Very strongly acidic & {$[21]$} \\
Organic carbon (\%) & 1.3 & Low & {$[22]$} \\
Organic Matter & 2.24 & Low & {$[22]$} \\
Total N (\%) & 0.08 & Very low & {$[22]$} \\
$\begin{array}{l}\text { Available P (mg kg } \\
\text { Available S }\left(\mathrm{mg} \mathrm{kg}^{-1}\right)\end{array}$ & 9.6 & Low & {$[23]$} \\
CEC [meq/100g soil) & 11.74 & Low & {$[13]$} \\
$\begin{array}{l}\text { Exchangeable Ca } \\
\text { (meq/100g) soil }\end{array}$ & 10.6 & Moderate & {$[21]$} \\
$\begin{array}{l}\text { Exchangeable Mg } \\
\text { (meq/100g) soil) }\end{array}$ & 7.7 & High & {$[16]$} \\
\hline
\end{tabular}

\subsection{Yield and Yield Components}

\subsubsection{Number of Pods Per Plant (NPPP)}

The main effect of varieties, NPS and the interaction had non-significance effect on number of pods per plant. However, variety Wello had the highest number of pods per plant (38.3) while variety Ethio-Yugoslavia produced the lowest number of pods per plant (Table 4). With regards to NPS rates, the highest number of pods per plant (40.9) was observed at NPS rate of $100 \mathrm{~kg} \mathrm{ha}^{-1}$ while the lowest number of pods per plant (32.0) was recorded in unfertilized treatments. Although the number of branches per plant increases as the fertilizer rate increases, the number of pods 
per plant was not increased. This may be due to abortion of flower at flowering initiation. Similar result was also reported in soybean where the application of 80-120 kg $\mathrm{P}_{2} \mathrm{O}_{5}$ $\mathrm{ha}^{-1}$ of soybean increased the number of pods plant ${ }^{-1}$ [24].

\subsubsection{Number of Seeds Per Pod (NSPP)}

The main effect of varieties, NPS and the interaction had non-significance influence on Number of seeds per pod. However, the highest number of Seeds per pods (2.47) was observed at NPS rate of $150 \mathrm{~kg} \mathrm{ha}^{-1}$ while the lowest number of Seeds per pods (2.40) was recorded in unfertilized treatments (Table 4). Number of seeds per pod increased with the increased application of NPS rates which might have been due to high N is in NPS rates and changed to vegetative part.

Nitrogen fertilizer had no significant influence on the number of seeds per pod of chickpea [25] Likewise, application of sulfur up to $60 \mathrm{~kg} \mathrm{ha}^{-1}$ had no significant effect on the number of grains per pod of common bean [26].

\subsubsection{Above-ground Dry Biomass Yield (AGDBY)}

The main effect of variety and the interaction had no significant effect on AGDBY, however, the main effect of NPS fertilizer rate had significant effect $(\mathrm{P}<0.05)$ on AGDBY. The highest $\left(8718 \mathrm{Kg} \mathrm{ha}^{-1}\right)$ was recorded from the application of highest rate of NPS fertilizer (200 kg NPS ha $\left.{ }^{1}\right)$, whereas the lowest $\left(6910 \mathrm{Kg} \mathrm{ha}^{-1}\right)$ biomass yield was obtained from nil NPS rate (Table 4). The result generally showed an increase in biomass production with increase in the rate of blended NPS fertilizer rate. This could be to the fact that the enhanced availability of $\mathrm{N}$ significantly increased plant height, number primary branches per plant and to the overall vegetative growth of the plants that contributed to higher aboveground dry biomass yield. This result was in line with total dry matter production increased significantly due to increased nitrogen application from 40 to $120 \mathrm{~kg} \mathrm{~N} \mathrm{ha}^{-1}$ on French bean (Phaseolus vulgaris) [27].

The same line is reported that application of $120 \mathrm{~kg} \mathrm{~N} \mathrm{ha}^{-1}$ significantly increased the dry weight of French bean [28].

The total above-ground dry biomass yield of faba bean significantly increased with increased rate of phosphorus fertilizer application, this is the same with application of sulfur up to $60 \mathrm{~kg} \mathrm{~S} \mathrm{ha}^{-1}$ and interaction of nitrogen with sulfur did not result in significant effect on above-ground dry biomass of common bean [24].

\subsubsection{Seed Yield}

The analysis of variance revealed that the seed yield was affected significantly $(\mathrm{P}<0.05)$ by the main effects of NPS fertilizer rate. However, the main effects of Variety and the interaction were non-significant influence on the seed yield.

The highest Seed yield $\left(2763 \mathrm{Kg} \mathrm{ha}^{-1}\right)$ was recorded due to the application of $\left(100 \mathrm{~kg} \mathrm{ha}^{-1}\right)$ NPS fertilizer rate, whereas the lowest Seed yield $\left(1935 \mathrm{Kg} \mathrm{ha}^{-1}\right)$ was obtained from the nil application of fertilizer rate (Table 4). It might also be due to increased levels of $\mathrm{S}$, its availability along with major nutrients and higher uptake of crop and influencing growth and yield components of the crop, which ultimately lead to effective, assimilate partitioning of photosynthesis from source to sink in post-flowering stage and resulted in highest seed yield. Generally, soybean grain yield consistently increased with increase in the rate of applied $\mathrm{N}$ to the optimum level of $\mathrm{N}$ and the grain yields recorded due to each successive rate of $\mathrm{N}$ were different from each other. Seed yield of soybean increased significantly at $40 \mathrm{~kg} \mathrm{~N} \mathrm{ha}^{-1}$ compared to the control treatment [29]. However, application of $80 \mathrm{~kg} \mathrm{~N} \mathrm{ha}{ }^{-1}$ decreased seed yield, indicating that there is a limit to the maximum level of nitrogen to be supplied to avoid its detrimental effect on the plant. This result might be attributed to the fact that applying NPS fertilizer increases crop growth and yield on soils which are naturally low in NPS and in soils that have been depleted [30]. This result is in line with; revealed as that application of phosphorus influenced the seed yield of French bean (Phaseolus vulgaris) significantly up to $60 \mathrm{~kg} \mathrm{P}_{2} \mathrm{O}_{5} \mathrm{ha}^{-1}$ [27]. In line with this result, application of $\mathrm{S}$ with or without $\mathrm{P}$ recorded significantly higher seed yield up to $40 \mathrm{~kg} \mathrm{~S}^{-1}$ on chickpea [31] and on black gram [32]. It might also be due to increased levels of $\mathrm{S}$, its availability along with major nutrients and higher uptake of crop and influencing growth and yield components of the crop, which ultimately lead to effective, assimilate partitioning of photo synthates from source to sink in post-flowering stage and resulted in highest seed yield. This reported increased yield response of pulses to seed inoculation of rhizobium $[33,34]$.

\subsubsection{Hundred Seed Weight (HSW)}

Hundred seed weights was found to be highly significantly $(\mathrm{P}<0.01)$ affected by soybean Variety. However, NPS application rates and the interaction effect were nonsignificant. Variety Wello gave the lowest hundred seed weight $(15.06 \mathrm{~g})$ as compared to other varieties. There was no significant difference between the other two varieties (Table 4). This indicates that the trait is mainly controlled by genetic factors than the management. In conformity with this result, significant differences among genotypes of chickpea on hundred seed weight [35]. In contrast to this results stated that the number of seeds per pod and weights of hundred seeds were strongly controlled genetically in field bean (Pisum sativim) [36].

Table 4. Mean number of above ground biomass (AGDB), hundred seed weight (HSW) and seed yield (SY) of soybean.

\begin{tabular}{llllll}
\hline Treatment & $\begin{array}{l}\text { Pod } \\
\text { /plant }\end{array}$ & Seed/pod & $\begin{array}{l}\text { AGDB } \\
\left(\mathbf{k g ~ h a}^{-1}\right)\end{array}$ & $\begin{array}{l}\text { HSW } \\
(\mathbf{g})\end{array}$ & $\begin{array}{l}\text { SY } \\
\left(\mathbf{k g ~ h a}^{-\mathbf{1}}\right)\end{array}$ \\
\hline $\begin{array}{l}\text { Varieties } \\
\text { Dhidhessa }\end{array}$ & 37.1 & 2.43 & 8311.0 & $16.77^{\mathrm{a}}$ & 2494 \\
$\begin{array}{l}\text { Ethio- } \\
\text { Yugoslavia }\end{array}$ & 34.0 & 2.43 & 7507.0 & $16.9^{\mathrm{a}}$ & 2399 \\
Wello & 38.3 & 2.43 & 7130.0 & $15.06^{\mathrm{b}}$ & 2416 \\
LSD (\%) & 5.71 & $\mathrm{NS}$ & $\mathrm{NS}$ & 0.93 & $\mathrm{NS}$ \\
NPS rate $\left(\mathrm{Kgha}^{-1}\right)$ & & & & \\
0 & 32.0 & 2.40 & $6910^{\mathrm{b}}$ & 16.22 & $1935^{\mathrm{b}}$ \\
50 & 33.2 & 2.43 & $7138^{\mathrm{b}}$ & 16.42 & $2347^{\mathrm{ab}}$ \\
100 & 40.9 & 2.40 & $8115^{\mathrm{ba}}$ & 16.02 & $2763^{\mathrm{a}}$ \\
150 & 36.3 & 2.47 & $7366^{\mathrm{b}}$ & 16.38 & $2451^{\mathrm{a}}$ \\
200 & 40.0 & 2.45 & $8718^{\mathrm{a}}$ & 16.16 & $2685^{\mathrm{a}}$ \\
LSD (\%) & $\mathrm{NS}$ & $\mathrm{NS}$ & 1241.6 & $\mathrm{NS}$ & 461.0 \\
\hline
\end{tabular}




\begin{tabular}{llllll}
\hline Treatment & $\begin{array}{l}\text { Pod } \\
\text { plant }\end{array}$ & Seed/pod & $\begin{array}{l}\text { AGDB } \\
\left(\mathbf{k g ~ h a}^{-1}\right)\end{array}$ & $\begin{array}{l}\text { HSW } \\
(\mathbf{g})\end{array}$ & $\begin{array}{l}\text { SY } \\
\left.\text { (kg ha }^{-1}\right)\end{array}$ \\
\hline CV (\%) & 20.9 & 8.9 & 16.8 & 7.7 & 20.1 \\
\hline
\end{tabular}

Means followed by the same letters are not significantly different as judged by $\mathrm{LSD}$ test at $5 \%, \mathrm{CV}=$ coefficient of variation, $\mathrm{AGDB}=\mathrm{Above}$ ground dry biomass, HSW= hundred seed weight, $\mathrm{SY}=$ seed yield.

\subsubsection{Harvest Index}

Harvest index of Soybean calculated as the ratio of Seed yield to the above ground dry biomass weight was nonsignificant due to the main effect of NPS fertilizer rate, variety and Interaction. This may be due to adequate supply of $\mathrm{N}$ and $\mathrm{S}$ is essential for optimizing partitioning of dry matter between seed and other parts of the soybean plant. Optimum utilization of solar radiation, higher assimilates production and its conversion to starch results in higher biomass, seed yield leading to higher harvest index.

\subsubsection{Economic Analysis}

The agronomic data upon which the recommendations are based must be relevant to the farmers' own agro-ecological conditions, and the evaluation of those data must be consistent with the farmers' goals and socio-economic circumstances [17].

The net benefit was computed due to Soybean varieties, application of blended NPS fertilizer and interaction of varieties with application of blended NPS fertilizer. The economic analysis revealed that highest net benefit $(21,457.2$ Birr $\mathrm{ha}^{-1}$ ) was obtained from combination of variety Dhidhessa with application of $100 \mathrm{~kg} \mathrm{NPS} \mathrm{ha}{ }^{-1}$ while the lowest net benefit (14327.9 Birr ha ${ }^{-1}$ ) was obtained from variety Ethio-yugoslavia with nil application fertilizer (Table 5). Generally, the three varieties gave the highest $100 \mathrm{kgha}^{-1}$ except Dhidhessa $+50 \mathrm{kgha}^{-1}$ suggesting $100 \mathrm{kgha}^{-1}$ recommendation for soybean is the best recommendation which is replacement with the blanket recommendation.

Table 5. Result of economic analysis for response of Soybean varieties to rates of blended NPS.

\begin{tabular}{|c|c|c|c|c|c|c|}
\hline Treatments & Adjusted yield $\left(\mathrm{kg} \mathrm{ha}^{-1}\right)$ & $\begin{array}{l}\text { NPS cost } \\
\left(\text { Birr ha }^{-1}\right)\end{array}$ & $\begin{array}{l}\text { NPS application } \\
\left(\text { Birr ha }^{-1}\right)\end{array}$ & $\begin{array}{l}\text { Total Cost } \\
\left(\text { Birr ha } \text { ha }^{-1}\right)\end{array}$ & $\begin{array}{l}\text { Total Revenue } \\
(\text { Birr ha-1) }\end{array}$ & $\begin{array}{l}\text { Net Benefit } \\
\left(\text { Birr ha }{ }^{-1}\right)\end{array}$ \\
\hline Dhidhessa +0 & $1,902.30$ & 0 & 0 & 0 & $17,120.75$ & $17,120.75$ \\
\hline Ethio-Yugoslavia +0 & $1,591.98$ & 0 & 0 & 0 & $14,327.9$ & $14,327.9$ \\
\hline Wello +0 & $1,729.85$ & 0 & 0 & 0 & $15,568.65$ & $15,568.65$ \\
\hline Dhidhessa +50 & $2,126.91$ & 638 & 275 & 913 & $19,142.19$ & $18,229.19$ \\
\hline Ethio-Yugoslavia +50 & $2,083.70$ & 638 & 275 & 913 & $18,753.38$ & $17,840.38$ \\
\hline Wello +50 & $2,409.54$ & 638 & 275 & 913 & $21,685.9$ & $20,772.9$ \\
\hline Ethio-Yugoslavia +100 & $2,418.71$ & 1,276 & 275 & 1,551 & $21,768.39$ & $20,217.39$ \\
\hline Wello +100 & $2,483.99$ & 1,276 & 275 & 1,551 & $22,355.91$ & $20,804.91$ \\
\hline Dhidhessa +150 & $2,162.08$ & 1,914 & 275 & 2,189 & $19,458.76$ & $17,269.76$ \\
\hline Ethio-Yugoslavia +150 & $2,190.95$ & 1,914 & 275 & 2,189 & $19,718.63$ & $17,529.63$ \\
\hline Wello +150 & $2,264.65$ & 1,914 & 275 & 2,189 & $20,381.9$ & $18,192.9$ \\
\hline Dhidhessa +200 & $2,474.82$ & 2,552 & 275 & 2,827 & $22,273.38$ & $19,446.38$ \\
\hline Ethio-Yugoslavia +200 & $2,508.24$ & 2,552 & 275 & 2,827 & $22,574.19$ & $19,747.19$ \\
\hline
\end{tabular}

Where, NPS cost $=1276$ Birr $/ 100 \mathrm{~kg}$, NPS application cost $=275 \mathrm{Birr} \mathrm{ha}^{-1}$, Soybean grain price of all Varieties $=9 \mathrm{Birr}_{\mathrm{kg}}{ }^{-1}$

\section{Summary and Conclusions}

Soybean yield is low compared to other legume crops due to many factors affecting its production which include suitable varieties, poor agronomic practices such as fertility management including appropriate fertilizer rate and time of application, untimely and inappropriate field operations, rainfall variability and diseases and insect pests. Therefore, field experiment was conducted during the 2018 main cropping season at Bako Agricultural Research Center to assess the effect of rates of blended NPS on yield and yield components of soybean varieties and to determine economically appropriate rates of blended NPS fertilizers for soybean production.

The treatment consists of three varieties of soybean (Dhidhessa, Ethio-yugoslavia and Wello) and five rates of NPS $\left(0,50,100,150\right.$ and $\left.200 \mathrm{~kg} \mathrm{ha}^{-1}\right)$. The experiment was laid out in factorial arrangement in randomization complete block design (RCBD) with three replications. The result of the analysis of soil samples showed that the soil of the experimental field is clay in texture and had $\mathrm{pH}$ of 4.84 , $2.24 \%$ of organic matter, $0.08 \%$ of total $\mathrm{N}, 1.3 \%$ of organic carbon, CEC of $23 \mathrm{cmol} / \mathrm{kgsoil}$, available phosphorus of 9.6 $\mathrm{mg} \mathrm{kg}{ }^{-1}$ and available sulfur of $11.74 \mathrm{mg} \mathrm{kg}^{-1}$. The highest $\left(2763 \mathrm{~kg} \mathrm{ha}^{-1}\right)$ seed yield was obtained from the application of $100 \mathrm{~kg} \mathrm{NPS} \mathrm{ha}^{-1}$ and the lowest (1935 kg ha-1) from the control.

Based on the partial budget analysis, the highest net benefit $\left(21,457.2\right.$ Birr ha $\left.^{-1}\right)$ was obtained from combination of variety Dhidhessa with application of $100 \mathrm{~kg} \mathrm{NPS} \mathrm{ha}^{-1}$ whereas lowest net benefit (14327.9 Birr ha $^{-1}$ ) was from variety Ethio-yugoslavia with application of nil NPS fertilizer. The major measured parameters contributing for grain yield were above ground biomass, number of pod per plant and no of primary branch per plant. This experiment generally confirmed as $100 \mathrm{kgha}^{-1}$ NPS for soybean was appropriate. In most measured traits /parameters the varieties used was not highly variable but Didhessa was the better variety on efficient applied fertilizer utilization. This trial was conducted at strong acid soil, these it is expected as the plants might not have access to use the applied fertilizer and if it 
was conducted with lime application the responses might be changed. Thus, it can be concluded that application of $100 \mathrm{~kg}$ $\mathrm{ha}^{-1}$ with variety Dhidhessa was found to be superior and can be used for soybean production in mid-land and similar agroecology. However, since the experiment was conducted for one season at one location, it has to be repeated over seasons and locations to make a conclusive recommendation.

\section{References}

[1] B. Amare. 1987. Research Program of IAR (Institute of Agricultural Research). Addis Ababa, Ethiopia.

[2] NSRL (National Soybean Research Laboratory). 2007. Soybean Nutrition. National Soybean Research Laboratory. http://WWW.Nsrl.Uluc.Educ/ about soybean.

[3] CSA (Central Statistical Agency). 2017. Agricultural Sample Survey 2016/2017: Report on Area and Production of Major Crops (Private Peasant Holdings, Meher Season). Volume-I, Statistical Bulletin 584, Addis Ababa, Ethiopia.

[4] G. Kidane, A. Amare, N. Adhanom, D. Legesse, and Y. Wold. 1990. Cereal/Legume Inter- cropping research in Ethiopia, p. 167-175. Proceeding of the Work shop on Research Methods for Cereal/Legumes Intercropping in Eastern and Southern Africa, Lilongwe. January 21-28, 1989, Mexico, CIMMYT.

[5] J. S. Boyer. 1982. Leaf enlargement and metabolic rates in Corn, Soybean and Sunflower at various leaf water potentials. Plant Physiology, 46: 233-235.

[6] E. C. Sample and Kamprath, E. J. 1980. The role of phosphorus in agriculture. Madison, WI: American Society of Agronomy. pp. 263-310.

[7] C. P. Vance, Uhde-Stone, C. and D. L Allan. 2003. Phosphorus acquisition and use: critical adaptations by plants for securing a nonrenewable resource. New phytologist, 157 (3), 423-447.

[8] K. E. Giller and Cadisch G. 1995. Future benefits from biological nitrogen fixation: an ecological approach to agriculture. Plant Soil 174: 255-277.

[9] R. J. Carsky, BB. Singh, and R. Oyewole, 2001. Contribution of early-season cowpea to maize in the savanna zone of West Africa. Biol. Agric. Hort. 18: 303-315.

[10] P W, Thies, Singleton and B. B. Bohlool. 1995. Phenology, growth, and yield of field grown soybean and bush bean as a function of varying modes of $\mathrm{N}$ nutrition, Soil Biology of Biochememistry. 27: 575-583.

[11] Y I. Gan, F. Stulen, H V. Posthumus, P. J. C Kuiper. 2002. Effects of N management on growth, N2 fixation and yield of soybean, Nutrient Cycle. Agroecosystem. (98): 121-130.

[12] D W. Barker, and J. E. Sawyer. 2005. Nitrogen application to soybean at early reproductive development. Agronomy. Journal. 97: 615-619.

[13] Ethiosis (Ethiopia Soil Information System). 2014. Soil fertility status and fertilizer recommendation atlas for Tigray regional state, Ethiopia. Ethiopia.

[14] M. L. Jackson. 1962. Soil Chemical Analysis. New Delhi, Prentice Hall of India Pvt. Ltd. 498p.
[15] L. P. Van Reewijk, 1992. Procedures for Soil Analysis ( $3^{\text {rd }}$ edition). International Soil Reference Center, Wageningen, Netherlands, 371p.

[16] FAO (Food and Agricultural Organization). 2008. Food and Agricultural Organization. Fertilizer and Plant Nutrition Bulletin. FAO, Rome, Italy.

[17] CIMMYT (Centro Internacional de Mejoramiento de Maiz y Trigo). 1988. From Agronomic Data to Farmer Recommendations: An Economics Work book. Mexico, D. F. CIMMYT.

[18] P. A. Hazelton and B. W. Murphy. 2007. Interpreting Soil Test Results: What Do All the Numbers Mean? CSIRO Publishing, Collingwood, Victoria, xip152 pp. 160 paperback. ISBN 9780-643092-25-9.

[19] M. Tekalign M. and I Haque. 1991. Phosphorus status of some Ethiopian soils, II. Forms and distribution of inorganic phosphates and their relation to available phosphorus. Tropical Agriculture 68: 1: 2-8.

[20] I. Bashour. 2007. Methods of Analysis for Soils of Arid and Semi-Arid Regions. In Rural Integrated Development of the Mountains of Northern Lebanon. FAO Report to Ministry of Agriculture, Beirut, Lebanon. Pp 128.

[21] P. Hazelton and B. Murphy. 2007. Interpreting Soil Test Results: What do all the Numbers mean?. CSIRO Publishing, Collingwood, Victoria, 2007.

[22] A. Subramanian and A. Radhak, 1981. Effect of foliar spray on black gram pulse crop. News L. India. 1: 39.

[23] T. Tades. 1991. Soil, plant, water, fertilizer, animal manure and compost analysis. Working Document No. 13. International Livestock Research Center for Africa, Addis Ababa, Ethiopia. and Subtropics. Longman Scientific and Technical, Essex, New York. 474p.

[24] I Bashour and A. H. Sayegh 2007. Methods of analysis for soils of arid and semi-arid regions. Published by foodand agricultural organization of United Nations, Rome.

[25] P Jayapaul and V. Ganesaraja, 1990. Studies on response of soybean varieties to nitrogen and phosphorus. Indian Journal of. Agriculture. 35: 329-30.

[26] N Ali and S. S Raouf. 2011. Phenological and morphological response of chickpea (Cicer artienium L.) to symbiotic and mineral nitrogen fertilization. Zemdiryste Agriculture, 2.

[27] T Nebret. 2012. Effect of nitrogen and sulphur application on yield components and yield of common bean (Phaseolus vulgaris L.) In Eastern Ethiopia. M.Sc. Thesis. Haramaya University of Agriculture, Haramaya. P. 23-25.

[28] N. K. Veeresh. 2003. Response of French bean (Phaseolus vulgaris $L$.) to fertilizer Levels in Northern transitional Zone of Karnataka. MSc. (Agriculture) Thesis, University Agricultural Science. Dharwad. P 37-79.

[29] L. R. Prajapati, Patil and B. M Patel. 2003. Effect of integrated weed management and nitrogen levels on weeds and productivity of French bean (Phaseolus vulgaris L.) Under north Gujarat conditions. Legume Research, 26: 77-84.

[30] A. Getachew and F Resene. 2006. Response of Faba bean to phosphorus fertilizer and weed control on Nitisols of Ethiopian Highlands. Italian Journal of Science, 2: 281-290. 
[31] P. Boroomandan, M Y. Khoramivafa and A. Ebrahimi. 2009. The effects of nitrogen starter fertilizer and plant density on yield, yield components, and oil and protein content of soybean (Glycine max, Merr.). Pakistan Biological Sciences Journal, 12 (4): 378-382.

[32] G. Mullins. 2001. Phosphorus, Agriculture and the Environment. Virginia Cooperative Extension, Virginia state university. No: 424-029.

[33] B. G. Shivakumar. 2001. Performance of chickpea (Cicer arietinum) varieties as influenced by sulphur with and without phosphorus. Indian Journal of Agronomy, 46 (2): 273-276.
[34] B. Desta. 1986. Biological nitrogen fixation research on grain legumes in Ethiopia: An Overview. In: Beck, D. P. and Materon, L. A. (Eds.). Proceedings of a Workshop on Biological Nitrogen Fixation on Mediterranean-Type Agriculture, Pp. 73-78. April14-17, 1986, ICARDA, Syria.

[35] S. V. Jawahar, V., Vaiyapuri, K. Suseendran, C. Kalaiyarasa. 2017 Sriramachandrasekharan 2017. Effect of sources and levels of sulphur on growth and yield of rice fallow blackgram (Vigna mungo). International Journal of Chemistry.

[36] A. Tanaka and K. Fujita, 1979. Growth, photosynthesis and yield components in relation to seed yield of the field bean. Journal of Faculty of Agriculture, 59: 145-238. 